\title{
Leadership Styles as a Challenge to Generate Innovation Environments in the Companies of the 21st Century
}

\author{
José G. Vargas-Hernández \\ $\mathrm{PhD}$, Research Professor, University Center for Economic and Managerial Sciences, University of \\ Guadalajara, Mexico

\section{Citlalli Rocío Flores Rodríguez} \\ $\mathrm{PhD}$ Candidate, University Center for Economic and Managerial Sciences, University of Guadalajara, Mexico
}

\begin{abstract}
The current challenge for the survival and growth of companies is the appropriation of innovation in all its senses, the generation of propitiating environments and the innovation philosophy acquisition into action; likewise improve internal dynamics and cohesion through a comparison of leadership styles; in other words, each organization requires a specific, adaptable combination and personality according to its characteristics, organizational culture and human capital, taking into account the needs, goals, and financial capital. It is analyzed aspects such as: leadership style, level of empowerment, organizational culture, sense of belonging, trust in the company and knowledge of human capital with the aim of proposing those current and relevant factors that combine to maintain the organization in a constant and permanent evolution, some authors have commented the importance of the culturally intelligent companies carry out innovation, likewise the styles of leadership and administration, will generate a collective consciousness tending to create innovational environments.
\end{abstract}

Keywords: innovative leadership, management styles, innovative environments, collective intelligence, cultural intelligence.

JEL Classification: M12, 031.

Cite as: Vargas-Hernández, J. G., Rodríguez, C. R. F. (2018). Leadership Styles as a Challenge to Generate Innovation Environments in the Companies of the 21st Century. Business Ethics and Leadership, 2(4), 64-73. http://doi.org/10.21272/bel.2(4).64-73.2018.

(C) The Authors, 2018. This article is published with open access at Sumy State University.

\section{Introduction}

The 21st century has a challenge for companies: taking innovation seriously, seen as appropriating innovation in all its forms in order to generate it. With this and for it, a particular and personalized mix of leadership, governance, knowledge of human capital and the creation of collaborative networks is required. The above in such a way that ecosystems of innovation are created, where actors of the companies, collaborators, partners, competition, and market form a synergistic system that promotes practices that lead to innovation.

Innovation in a global world is the common denominator towards success in the reality of the global economic environment of constant dynamism, which requires innovation as a fundamental idea for the holistic appropriation of innovation in companies. According to Drucker (1985), innovation is of vital strategic importance in management as a survival mechanism for corporations. Among the main factors for innovation Whiting and Solomon, (1989) are the willingness to take risks, the generation of creative ideas, and the adaptability to entrepreneurial spirituality.

Taking into account the importance of innovation, it is worth mentioning that its impact is not only internally, such as Schumpeter's definition of Innovation (1961) where some activities inherent to business innovation are established, such as: the introduction into the market of a new good, the introduction of a new production method, the opening of a new market, the conquest of a new source of supply as well as the implementation of a new structure in a market (Schumpeter, 1961). Some research has shown that a leading factor to obtain and follow a pattern of innovation within organizations is the leaders followed by a systemic approach to the above in order to obtain a relatively stronger and closer relationship with the improvement in organizational performance and driving towards innovation (Abbas and Asghar, 2010).

Other very important characteristics recently mentioned for companies and their members are mentioned by Livermore (2010) who comments only the culturally intelligent companies carry out the innovation, likewise, the styles of leadership and administration will generate a collective conscience tending to create environments 
of innovation. Leadership style is one of the most important factors to consider, as the leaders are those individuals who establish the direction of the work and guide the collaborators in the direction of fulfilling the goals of the company by motivating each member who has gained their trust (Conger, 1992).

\section{Background}

Among the factors that limit the development of nations are the "lack of financing, difficulties to exploit technology, limited managerial skills, low productivity, and regulatory burdens" (OECD, 2000: 1; Guellec, and Potterie, 2000). In the present investigation the limitations of managerial capacities as well as the difficulties to exploit the technology will be addressed; both factors related to a low knowledge of human capital as well as to the limited appropriation of innovation in all its areas of the company in a systemic way, in other words the two limitations mentioned above prevent the appropriation of techniques, philosophy and styles of leadership and management of the company in favor of the creation of innovation environments.

To understand the importance of the elements of a company Marvel, Rodríguez, and Núñez (2011: 3) have established that an organization can be seen as a micro-environment, a cluster of open and limited sets and subsets in space and time, composed of individuals, positions and areas of work, their activities, capabilities and a variety of elements, both physical and natural environment as well as cultural. The work environment is made up of general elements such as economic, social, legal aspects, etc. Operational aspects such as customers, employees and suppliers and internal elements such as culture, organizational climate, processes, leadership styles among others, in general aspects exert their strength in the direction and performance of the same.

There are indicators that reflect how well the resources of an economy are being used in production, that is, any company that has noticed deficiencies or underutilization of its resources and capacities can see the importance of improving processes and ways of doing things being able to integrate the new highly technological companies, and in constant innovation. Sar and Werneke (1984) refer to a relationship between the resources used and the products obtained and denotes the efficiency with which human resources, capital, knowledge, energy, etc. They are used to produce goods and services in the market.

Now who carries out the innovation are the subjects that are involved in it, actors such as: employees, directors, employees, and investors, put their capabilities in favor of the objectives and the survival of the company. If a company had identified the best elements hypothetical greater competitive advantage would be achieved. To confirm the above, this research analyzes studies identifying the most important elements and features that facilitate innovation in each area of a company, people with characteristics and/or tending attributes to innovation in a visible way, therefore the existence of the present Rubio (2015). Researchers have detected approaches with variable results: using demographic data and socioeconomic characteristics to identify the characteristics of subjects that facilitate the appropriation and creation of innovative environments, focusing on how to put into practice their capacity in favor of innovation.

Researchers such as Livermore (2010) have points of view based on their studies to culturally intelligent companies, which are responsible for the creation of innovation i.e. companies that have managed to understand the differences given by the environment and the culture of the subjects give a clear vision of the attitude and responses to ways of interacting within an organization. The former as a result of creating relationships of trust, commitment, internal influence, the authenticity of each member and the known positive intent, in such a way that the creation of innovation can be encouraged based on a collective intelligence.

Researchers such as Gloor (2006), define collective intelligence as a set of self-motivated individuals with a collective vision, encouraged by collaborating in the search for a common goal, sharing ideas, information, work and therefore skills.

Livermore (2010) raises the cultural intelligence quotient as one that identifies the differences given by the environment to a subject and that can be a factor of innovation. This concept measures the skill and ability to function effectively in a variety of ways: organizational, national, political, cultural and ethnic scenarios. On the other hand, Livermore (2010) also mentions that cultural intelligence is an essential capacity in order to achieve business success. The well-identified elements that make up cultural intelligence are: enthusiasm or motivation, knowledge, strategy, and action, adaptability of behavior to different cultures.

To improve the potential and skills of human capital are highlighted those points developed by Chiavenato and Villamizar, (2009) where it is pointed out that the survival of organizations depends on the appropriate use that is given to human capital and inherent to it especially its intellectual capital (knowledge, experiences, and cognitive abilities), it is emphasized that the investment of a company must include the development of intellectual capital to be able to bet on an improvement in the future. 


\section{Methods}

This article corresponds to a qualitative research based on a review of the literature about factors that companies must possess to appropriate innovation through innovative leadership and forms of administration appropriate to the needs of the $21^{\text {st }}$-century companies. Nature is exploratory and qualitative through the analysis of previous research trying to provide quality and flexibility that allows researchers to use multiple data collection methods (Dooley, 2002). Likewise, Merriam (1998) comments that flexibility is always the main strength of the strategy of a study.

The stages are:

Collection of information from indexed journals and academic bases.

Exploratory phase of the characteristics of leaders.

Concentration and order of theories.

Piloting of surveys with leaders with characteristics.

Analysis of information.

Analysis of results.

Conclusions.

Now, because of the nature of reality, the present investigation focuses on the psychological aspects of the individual, his way of solving problems, and his attitudinal and behavioral characteristics. In other words, through an interpretative vision of the results of the variables, the correlation between them and the subject of study will be verified, confirmed, or refuted with the intrinsic innovation present in the subjects; this will correspond to our analysis phenomenon.

Dependent variable:

Innovation scale of the leaders.

Independent variables:

a. Confidence and self-determination.

Table 1. Variables of confidence and self-determination.

\begin{tabular}{|l|l|}
\hline $\begin{array}{l}\text { 2.-How much are you willing to risk a new activity that you do } \\
\text { not know everything about? }\end{array}$ & Level of taking risks \\
\hline 3.-How often do you complete your goals? & Complete goals and objectives that are proposed \\
\hline 4.-How much will you persevere to achieve your goals? & Self-determination \\
\hline 7.-How much do you trust yourself and others? & Confidence in yourself. \\
\hline $\begin{array}{l}\text { 13.-Level of tenacity with which you determine that the problems } \\
\text { will not stop you? }\end{array}$ & Perseverance \\
\hline
\end{tabular}

Source: Own elaboration

b. Creativity and ingenuity

Table 2. Variables of creativity and ingenuity

\begin{tabular}{|l|l|}
\hline 1.-How often do you use your wits on a day-to-day basis? & Frequency of the use of ingenuity and inventiveness. \\
\hline 9.-How creative do you consider yourself? & Creativity \\
\hline $\begin{array}{l}\text { 10.-Do you usually personalize your activities and jobs and put } \\
\text { yourself in it? }\end{array}$ & Authenticity and originality \\
\hline
\end{tabular}

Source: Own elaboration

c. Self-knowledge and self-monitoring

Table 3. Variables of self-knowledge and self-monitoring

\begin{tabular}{|l|l|}
\hline 6.-In all honesty that you trust in yourself? & Honesty \\
\hline $\begin{array}{l}\text { 7.-Do you think that your ideas are intelligent, relevant and } \\
\text { important? }\end{array}$ & Self-confidence \\
\hline 8.-Do you know the worst and the best of yourself? & Self-knowledge \\
\hline $\begin{array}{l}\text { 11.-Do you usually do things your way, so that it is evident that } \\
\text { something was created by you? }\end{array}$ & Authenticity \\
\hline $\begin{array}{l}\text { 12.-Do you know when you did something by putting the best of } \\
\text { you and when not? }\end{array}$ & Self-monitoring \\
\hline
\end{tabular}

Source: Own elaboration 
d. Teamwork and collaboration

Table 4. Variables of teamwork and self-determination

\begin{tabular}{|l|l|}
\hline $\begin{array}{l}\text { 5.-Do you usually support others when your knowledge is } \\
\text { greater? }\end{array}$ & Level of collaboration \\
\hline $\begin{array}{l}\text { 6.-Do you support your colleagues and -or collaborators to meet } \\
\text { their challenges. }\end{array}$ & Teamwork \\
\hline 12.-What is your priority in life? & Level of ambition-altruism \\
\hline $\begin{array}{l}\text { 14.-You look for help and offer your help when someone needs it } \\
\text { or when you can give away your time and your knowledge. }\end{array}$ & Level of altruism. \\
\hline
\end{tabular}

Source: Own elaboration

\section{Assumptions}

A. When there is leadership, empathic tending to $\mathrm{X}$ and $\mathrm{Y}$ theories, adaptable, as well as transformational, the presence of innovation environments is favored and therefore there will be more innovation.

B. Culturally smart companies improve the appropriation of innovation and the permanence of innovators in it.

\section{Literature review}

From another point of view, the most important aspects necessary to generate innovation environments include variables such as motivation, cognition, metacognition, and behaviors that are included in tools for the measurement of cognitive capacity (Zulma, 2006).

In terms of capital and cultural knowledge, Gillezeau (2011) analyzes certain elements that facilitate the skill or ability of companies to function effectively with people belonging to diverse environments and cultures, using their different skills, knowledge and abilities in an efficient manner to harmonize the relationship between the subjects within an organization and the organization itself, elements such as: culture, attachments, nature, values, emotions, sense of equity of the environment, actions of collaborators, organization and processes are mentioned.

Now not all the context of an organization involves its human or intellectual capital, the rules of the game and interaction are given by leadership styles. For it, Rich Lyons (2011) highlights the capabilities that an innovative leader should have where he mentions: ability to define opportunities, identify problems, recognize opportunities and know how to experiment, decision-making capacity, choice and assessment of ideas and mention the cognitive aspect of the leaders themselves that involves knowledge of models and risk selection. Finally, the leader must possess the ability to increase and manage the capacity of the organization through the use of influence without using authority, conflict management, the impulse of the creativity of his team and the use of adaptive governance.

One of the most recent terms is that of cultural intelligence itself that is described as the interest and confidence of the person to function effectively in culturally diverse environments. This term encompasses the person's knowledge, cognition, experiences and ideas on how the cultures are similar and different. It helps to improve judgments about one's own or others' thought processes, as well as the person's ability to adapt their behavior to different cultures. It requires having a flexible repertoire of responses to adapt to different situations while remaining true to oneself, and is, therefore, an indispensable element in the leaders of the present to generate environments where there are equality and understanding of cultural differences (Depaula and Azzollini, 2012).

Table 5. Comparison of leadership styles and administration

\begin{tabular}{|l|l|l|}
\hline \multicolumn{1}{|c|}{ Comparisons of management styles and leadership } & \multicolumn{1}{|c|}{ Authors } & \multicolumn{1}{|c|}{ Theories } \\
\hline $\begin{array}{l}\text { According to Mintzberg (1985), it is a detailed monitoring system of actions very similar to } \\
\text { an ideal, which makes planning and action strategies. }\end{array}$ & $\begin{array}{l}\text { Mintzberg, y } \\
\text { Organizations require articulated objectives, clear divisions of work, clearly defined tasks, } \\
\text { well-developed hierarchies, and formalized control systems. }\end{array}$ & $\begin{array}{l}\text { McHhocracy } \\
\text { (1985). }\end{array}$ \\
\hline $\begin{array}{l}\text { Promotes productivity, employee satisfaction, more confidence, and stable employment. In } \\
\text { addition, this theory is also influenced by the Japanese management style, where the most } \\
\text { important element in companies is the correct management of their human resources. }\end{array}$ & Ouchi (1982). & Theory Z \\
\hline
\end{tabular}


Table 5 (cont.). Comparison of leadership styles and administration

\begin{tabular}{|c|c|c|}
\hline Comparisons of management styles and leadership & Authors & Theories \\
\hline $\begin{array}{l}\text { Management is responsible for promoting, through good practices, meeting the needs of the } \\
\text { company along with social needs, the needs of self-fulfillment, and the ego of subordinates; as } \\
\text { well as the mutual objectives of the company. It places special emphasis on management as } \\
\text { well as on the same motivational management that promotes better conditions and good } \\
\text { devices to encourage motivated practices, self-regulated behavior, an adequate work } \\
\text { environment and, consequently, better productivity results. }\end{array}$ & $\begin{array}{l}\text { Mc Gregor } \\
(1960) \text {. }\end{array}$ & Theory Y \\
\hline $\begin{array}{l}\text { Managers control their own performance, stronger motivation, higher performance objectives, } \\
\text { and a broader vision; the direction is towards managing teams, it also includes the } \\
\text { "measurement" of good practices and the results of them. } \\
\text { It raises high standards of quality in processes, as well as in reports and procedures. } \\
\text { This approach requires the subordinate to establish short-term performance objectives for } \\
\text { himself. } \\
\text { The superior enters the process actively reflects and makes a careful assessment of their own } \\
\text { strengths and weaknesses, as well as their subordinates to formulate specific plans to achieve } \\
\text { their objectives. }\end{array}$ & $\begin{array}{l}\text { Druker } \\
(2013) \\
(2007)\end{array}$ & $\begin{array}{l}\text { Management } \\
\text { by Objectives }\end{array}$ \\
\hline $\begin{array}{l}\text { Model in which the process and the consequences of the efforts to exert control and influence } \\
\text { on the decisions affect the functioning of the organization and the quality of the life of the } \\
\text { community. } \\
\text { The value orientation of empowerment suggests goals, objectives, and strategies for } \\
\text { implementing change. Likewise, it provides principles and a framework to organize the } \\
\text { activities of the company and the internal management of knowledge, empowerment is } \\
\text { visualized as an intentional and continuous process focused on the local community, which } \\
\text { implies mutual respect, critical reflection, responsibility, loyalty, trust, caring and group } \\
\text { participation. }\end{array}$ & $\begin{array}{l}\text { Zimmernan, } \\
(2000) ; \\
\text { Rappaport, } \\
(1981) ; \\
\text { Zimmerman, } \\
\text { y } \\
\text { Warschausky, } \\
(1998) .\end{array}$ & Empowerment \\
\hline $\begin{array}{l}\text { It describes three levels of Top, Middle and Frontline management as defined degrees of power } \\
\text { that expand leadership capabilities, creating a solid distribution of significant leadership } \\
\text { performance throughout the organization. } \\
\text { Distribute leadership at all levels of management. } \\
\text { These authors have proposed four steps to make it real in an organization } \\
\text { 1. See the reality of leadership } \\
\text { 2. Develop alternative leadership profiles } \\
\text { 3. Select potential leadership profiles. } \\
\text { 4. Institutionalize new leadership practices. }\end{array}$ & $\begin{array}{l}\text { Kim, y } \\
\text { Mauborgne, } \\
\text { (2017). }\end{array}$ & $\begin{array}{l}\text { Leadership } \\
\text { CANVAS }\end{array}$ \\
\hline $\begin{array}{l}\text { Masood (2006) Considers a Gestalt strategy based on organic structures and some other } \\
\text { elements such as: enthusiasm of creation; the unexpected but convincing sense of mission; and } \\
\text { the appointment of a highly charismatic leader, who could resist bureaucratic pressures and } \\
\text { exploit the first two factors to boost the organization in a course of enthusiasm and excellence. }\end{array}$ & $\begin{array}{l}\text { Masood, } \\
\text { Dani, Burns, y } \\
\text { Backhouse } \\
(2006) \text {. }\end{array}$ & $\begin{array}{l}\text { Charismatic } \\
\text { leadership }\end{array}$ \\
\hline Emotional leadership based on staff knowledge and self-knowledge & $\begin{array}{l}\text { Vitello- } \\
\text { Cicciu, } \\
(2003)\end{array}$ & $\begin{array}{l}\text { Emotional } \\
\text { intelligence } \\
\text { and innovative } \\
\text { leadership }\end{array}$ \\
\hline $\begin{array}{l}\text { Leadership as a central factor in the evolution and cultivation of an organization, the process } \\
\text { of organizational change and the high demand for effective and highly competent leadership } \\
\text { capable of perceiving the most desirable form of an organization along with organizational } \\
\text { changes. }\end{array}$ & $\begin{array}{l}\text { Abbas, y } \\
\text { Asghar, } \\
(2010) .\end{array}$ & $\begin{array}{l}\text { Innovative } \\
\text { leadership }\end{array}$ \\
\hline
\end{tabular}

Source: Prepared by the authors April 30, 2018

Table 6. Important factors for generating innovation environments. Exploratory phase of the characteristics of leaders

\begin{tabular}{|l|l|}
\hline Gillezeau (2011) & $\begin{array}{l}\text { Knowledge in culture, attachments, nature, values, emotions, feeling of equity in the environment, } \\
\text { actions of collaborators, organization, and processes. }\end{array}$ \\
\hline Prahalad y Hamel (1993) & $\begin{array}{l}\text { The capacities the more they are used the more they are perfected. - To use in a constant way those } \\
\text { capacities that stimulate the creativity and therefore the innovation. }\end{array}$ \\
\hline Rich Lyons (2011) & $\begin{array}{l}\text { The capacities that leaders of innovative environments should have: the ability to define } \\
\text { opportunities, identify problems, recognize opportunities and know how to experiment, decision- } \\
\text { making capacity, choice and evaluation of ideas and mention the cognitive aspect of leaders } \\
\text { themselves that involves knowledge of models and risk selection. }\end{array}$ \\
\hline $\begin{array}{l}\text { Domingo Depaula, P., \& } \\
\text { Celeste Azzollini, S. (2012) }\end{array}$ & $\begin{array}{l}\text { Cultural intelligence, values and motivation factors, ability to function effectively in a variety of } \\
\text { national, ethnic and organizational environments. }\end{array}$ \\
\hline Fontalvo, S. M. I. (2017) & Leadership, and behavior skills in pursuit of innovative strategic thinking \\
\hline Middlemist \& Hitt (1981) & $\begin{array}{l}\text { Positive and high influence on employees, know how to perform routine tasks, is respectful and } \\
\text { direct in their interactions and personal relationships within the work. }\end{array}$ \\
\hline
\end{tabular}

Source: Own elaboration 
To achieve the objective of this work, assess the traits and characteristics of the individual associated with innovation, it could be analyzed the increase in the degree of improvement of certainty in business success; that is, assigning the most suitable activity to the most suitable person. The present study focuses on the personal and environmental aspects that foster innovative subjects and leaders, as well as attitude and aspects of the personality Rodríguez and Prieto (2009).

\section{Results}

\section{A. Test of Variables}

\section{Confidence and self-determination}

\section{Statistics}

Confidence and self-determination $(2,3,4,7,13)$ (Grouped)

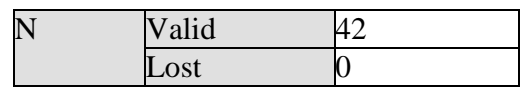

\begin{tabular}{|l|l|l|l|l|l|}
\hline \multicolumn{2}{|c|}{} & & & & Percentage \\
\multicolumn{2}{|c|}{} & Frequency & Percentage & Percentage valid & $\begin{array}{l}\text { accumulated } \\
\text { Valid }\end{array}$ \\
\cline { 2 - 6 } & Unfavorable & 5 & 11.9 & 11.9 & 11.9 \\
\cline { 2 - 6 } & Favorable & 29 & 69.0 & 69.0 & 81.0 \\
\cline { 2 - 6 } & Very Favorable & 8 & 19.0 & 19.0 & 100.0 \\
\cline { 2 - 6 } & Total & 42 & 100.0 & 100.0 & \\
\hline
\end{tabular}

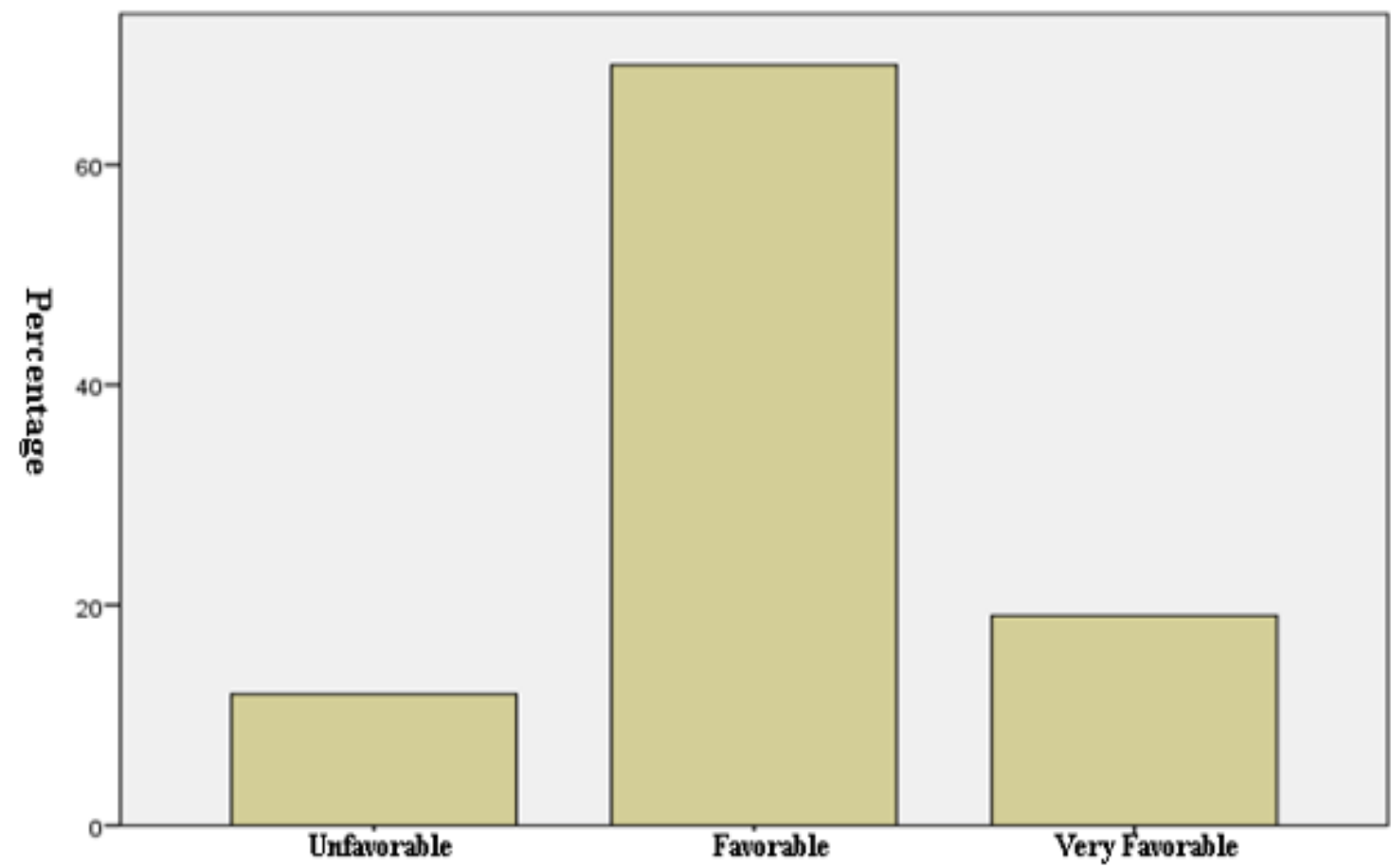

Source: Own elaboration

Figure 1. Confidence and self-determination $(2,3,4,7,13)$ (Grouped)

\section{Creativity and ingenuity}

Statistics

Creativity and ingenuity $(1,9,10)$ (Grouped)

\begin{tabular}{|l|l|l|}
\hline \multirow{N}{*}{$\mathbf{n}$} & Valid & 42 \\
\cline { 2 - 3 } & Lost & 0 \\
\hline
\end{tabular}

\begin{tabular}{|l|l|l|l|l|l|}
\hline \multicolumn{2}{|c|}{} & Frequency & Percentage & Percentage valid & $\begin{array}{l}\text { Percentage } \\
\text { accumulated }\end{array}$ \\
\hline \multirow{4}{*}{ Valid } & Very unfavorable & 1 & 2.4 & 2.4 & 2.4 \\
\cline { 2 - 6 } & unfavorable & 9 & 21.4 & 21.4 & 23.8 \\
\cline { 2 - 6 } & Favorable & 26 & 61.9 & 61.9 & 85.7 \\
\cline { 2 - 6 } & Very Favorable & 6 & 14.3 & 14.3 & 100.0 \\
\cline { 2 - 4 } & Total & 42 & 100.0 & 100.0 & \\
\hline
\end{tabular}




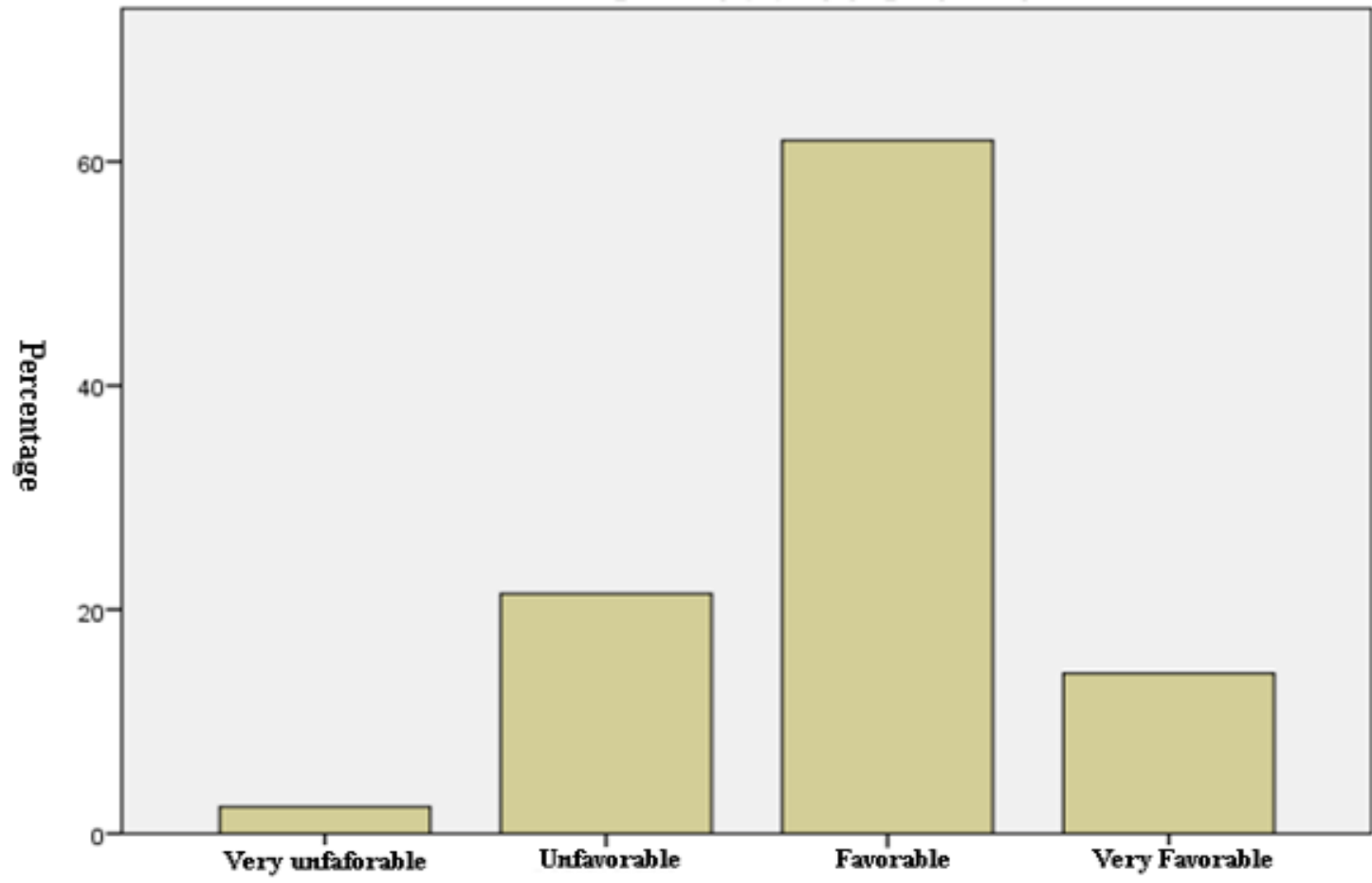

Source: Own elaboration

Figure 2. Creativity and ingenuity $(1,9,10)$ (Grouped)

\section{Self-knowledge and self-monitoring}

Statistics

Self-knowledge and self-monitoring $(6,8,11,12)$ (Grouped)

\begin{tabular}{|l|l|l|}
\hline \multirow{N}{*}{$N$} & Valid & 42 \\
\cline { 2 - 3 } & Lost & 0 \\
\hline
\end{tabular}

\begin{tabular}{|l|l|l|l|l|l|}
\hline \multicolumn{2}{|c|}{} & Frequency & Percentage & Percentage valid & Percentage accumulated \\
\hline \multirow{5}{*}{ Valid } & Unfavorable & 13 & 31.0 & 31.0 & 31.0 \\
\cline { 2 - 6 } & Favorable & 15 & 35.7 & 35.7 & 66.7 \\
\cline { 2 - 6 } & Very Favorable & 14 & 33.3 & 33.3 & 100.0 \\
\cline { 2 - 6 } & Total & 42 & 100.0 & 100.0 & \\
\hline
\end{tabular}

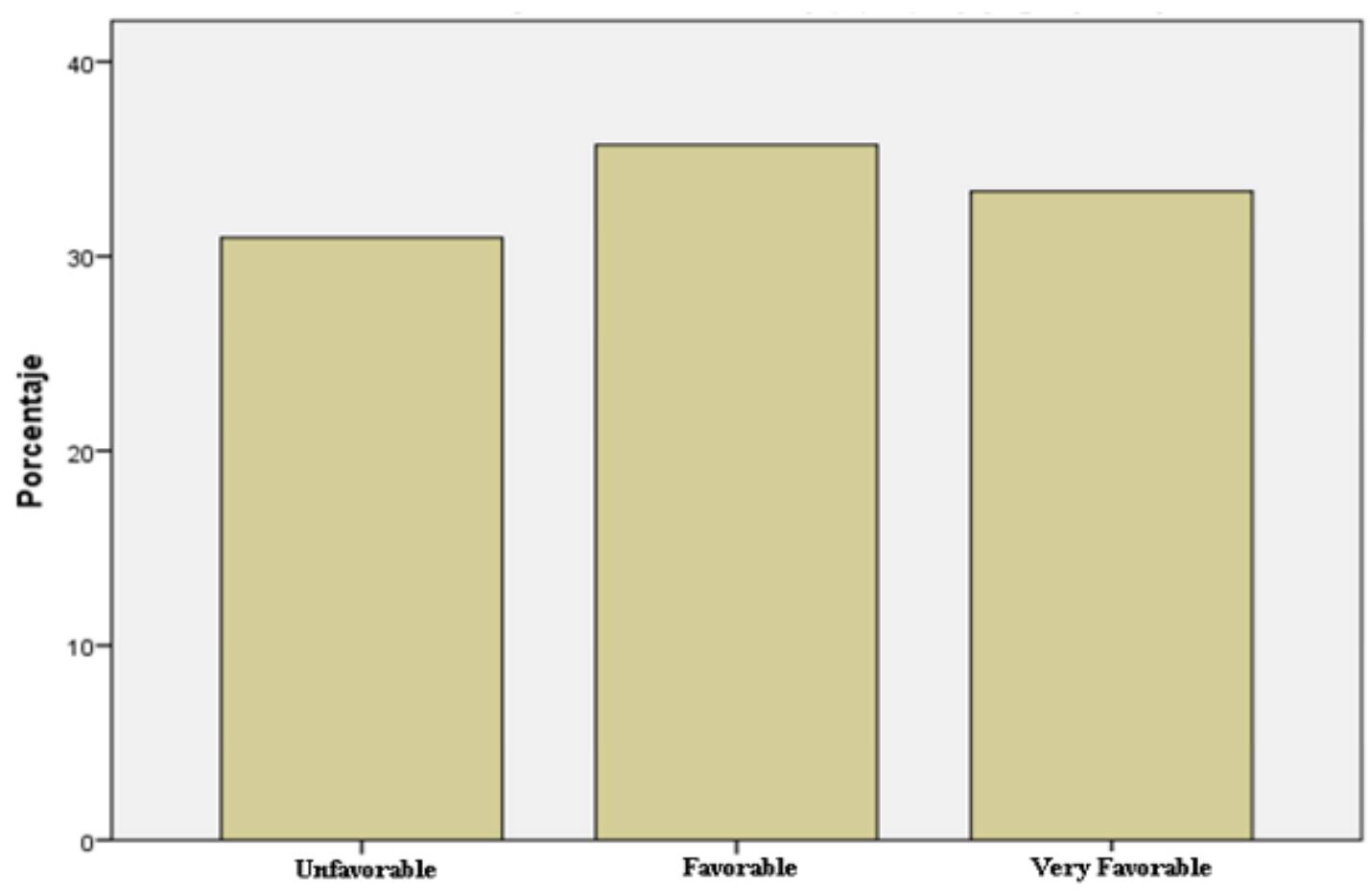

Figure 3. Self-knowledge and self-monitoring $(6,8,11,12)$ (Grouped) 


\section{Teamwork and collaboration}

\section{Statistics}

Teamwork and collaboration $(5,14)$ (Grouped)

\begin{tabular}{|l|l|l|}
\hline \multirow{N}{*}{$\mathbf{N}$} & Valid & 42 \\
\cline { 2 - 3 } & Lost & 0 \\
\hline
\end{tabular}

\begin{tabular}{|l|l|l|l|l|l|}
\hline \multirow{3}{*}{ Valid } & Frequency & Percentage & Percentage valid & Percentage accumulated \\
\cline { 2 - 7 } & Very unfavorable & 1 & 2.4 & 2.4 & 2.4 \\
\cline { 2 - 7 } & Unfavorable & 7 & 16.7 & 16.7 & 19.0 \\
\cline { 2 - 7 } & Favorable & 21 & 50.0 & 50.0 & 69.0 \\
\cline { 2 - 6 } & Very Favorable & 13 & 31.0 & 31.0 & 100.0 \\
\cline { 2 - 6 } & Total & 42 & 100.0 & 100.0 & \\
\hline
\end{tabular}

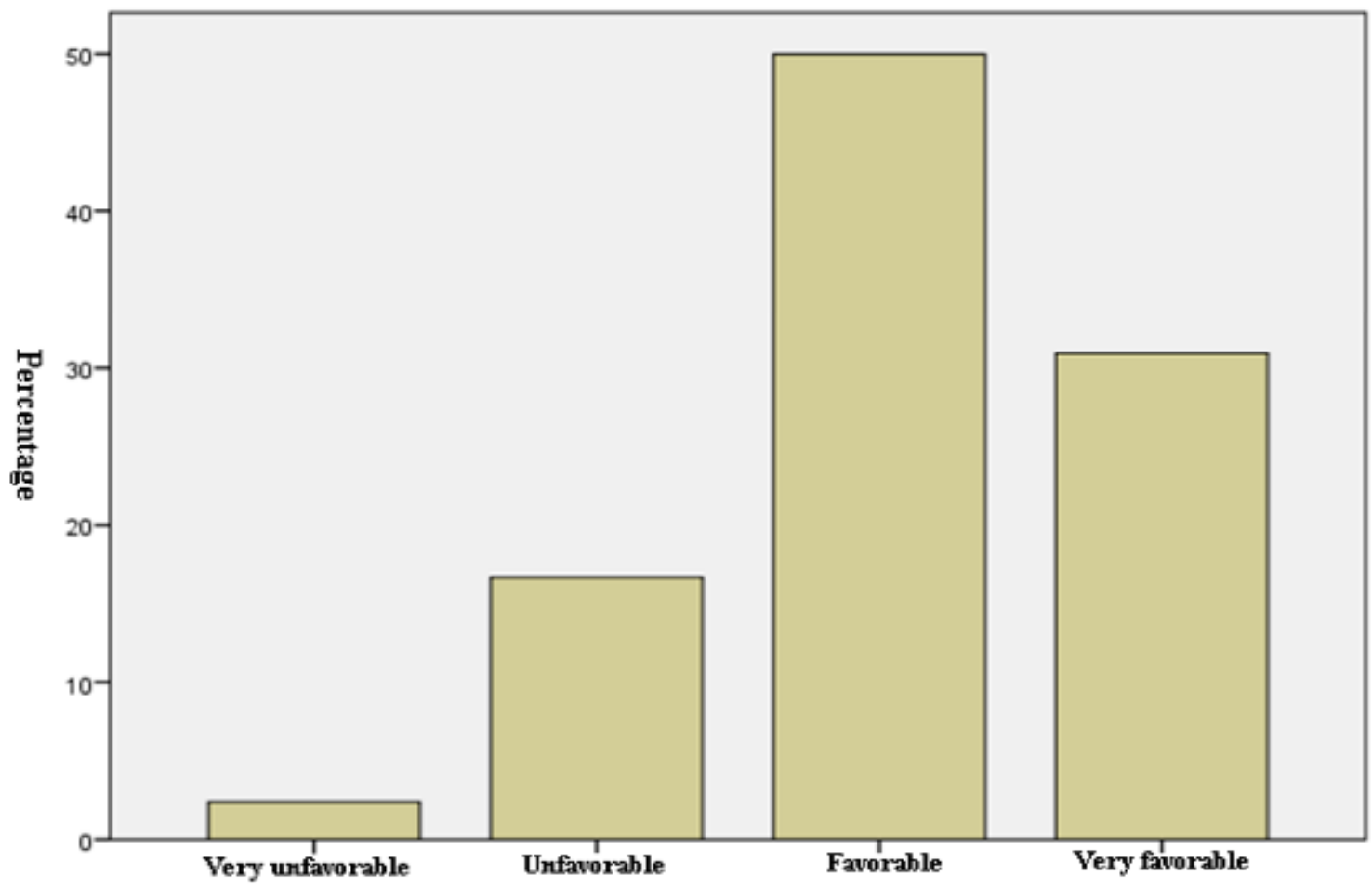

Figure 4. Teamwork and collaboration $(5,14)$ (Grouped)

Source: Own elaboration

Through this exercise, we were able to determine that less than 7 people out of 60 possess the trait of selfdetermination therefore only those 7 personnel would qualify favorable in the analysis.

\section{Creative variable}

At the level of creativity, as can be seen, there are more than 23 subjects who can qualify as favorable in their degree of creativity, therefore only they would go to the next stage.

\section{Variable disruptivism}

In the degree of adaptation to abrupt or disruptive changes is the balance for some people tending towards more positive results. In this aspect, we find a higher percentage of favorable. This may only reflect the task but a generalized situation of human capital.

Most believe that their level of disruption is favorable, that is, their way of accepting changes in dynamic environments.

\section{Variable entrepreneurial intention}

The majority of the respondents $96 \%$ think that their level of entrepreneurship is favorable, that is, their way of promoting an entrepreneurial culture.

\section{Variable motivation for entrepreneurship}

The majority of respondents also share their entrepreneurial motivation and innovation. Lack of motivation is one of the main factors in not welcoming innovation in all its areas, since if the benefits are not known from the beginning of a new proposal the employee may believe that he will be fired. 


\section{B. Analysis of results}

As it can be seen, the styles of leadership and administration vary from one era to another. In the most modern versions, it can be identified some concepts such as: systemic or organizational change, systemic management, and leadership, emotional skills and abilities, emotional intelligence and ability to collaborate.

Another challenge to generate innovation environments is the awareness of the internal and external cooperation for innovation. That is to allow endogenously and exogenously the companies to access knowledge and technology that they would not have been able to achieve on their own, to manage the knowledge in such a way that internal processes are disseminated, collaborate with companies from different sectors to share successful processes and ultimately generate synergies, as partners, collaborators and companies learn from each other.

Resilience is a basic value required to obtain new managerial structures, leadership styles, and innovative practices. The actions of organizational imitation can also be useful for the view of the short period of time, but not long because innovation requires personalized internal creative performance (Velasco and Ramírez, 2013).

\section{Proposals}

The list of components that innovative companies require as a proposal of this will be, therefore:

1) Flexible, situational, transformational leadership depending on the company, its organizational culture, its goals and the phase of ownership of innovation.

2) The administration must allow the empowerment of employees and staff to hold them responsible for the good or malfunctioning of the system and generate an internal understanding of their part in the process.

3) As regards the organizational climate, the number of aspects related to culturally intelligent companies should be improved.

4) The leaders of the innovation must have in their diary to act as common denominators of trust in their collaborators, commitment to the organization and with themselves, values, have recognition by the organization to improve their power to influence; likewise, be a person with authenticity and objective and positive attitude.

5) Improve the level of resilience.

\section{Conclusions}

Concluding with this analysis, we refer to a phrase by Porter that mentions that nothing harms more than the words and behavior of important individuals being unconscious of their words and actions. The above is a reflection of the need to consciously involve the superiors of companies to achieve true changes. On the other hand, the changes will be impossible if the attitude of the collaborator is not consistent and congruent with the philosophy of the organization's interests and values.

Similarly, managerial styles cannot be exactly aligned with company ideals or leaders' beliefs due to the fact that intrinsic interests or beliefs are involved in most cases. The ethical components such as: preferences and corruption that affect the acquisition of long-term innovation and the loyalty of employees are also involved in decision-making.

According to the results, co-responsibility between superiors and subordinates is necessarily necessary if the company is really considering this as an opportunity to continue growing and evolving.

The evidence and results show the effect of corporate culture on organizational performance, organizational commitment, job satisfaction, as well as the effect of managerial leadership style, organizational commitment, job satisfaction, etc.

As technological changes have emerged, new management practices are also needed.

Delegating is the right way to take leadership in these times when companies can have both, satisfy basic human needs as well as the growth desires and aspirations of its members at the same time.

\section{References}

1. Abbas, W., \& Asghar, I. (2010). The Role of Leadership in Organizatinal Change: Relating the successful Organizational Change with Visionary and Innovative Leadership. University of Gävle, Faculty of Engineering and Sustainable Development, Department of Industrial Development, IT and Land Management. Independent thesis Advanced level.

2. Chiavenato, I. (2009). Gestión del talento humano: el nuevo papel de los recursos humanos en las organizaciones McGraw-Hill [Managing talented people: A new role for human resources in McGraw-Hill organizations], México D.F. 
3. Fontalvo, S. M. I. (2017). Habilidades de liderazgo para una cultura de innovación en la gerencia de las universidades del distrito de Santa Marta. Academia y Virtualidad, 10(1).

4. Gillezeau, P. (2011). La cultura organizacional en el desarrollo de empresas inteligentes. Fundamentos: Valores, Comunicación y Liderazgo [Organizational culture in the development of smart companies. Fundamentals: Values, Communications and Leadership]. Telos, 1(2), 221-232.

5. Guellec, D., \& de la Potterie, B. V. P. (2000). The Impact of Public R\&D Expenditure on Business R\&D, OECD Publishing.

6. Conger, J.A, (May, 1992). Reflections on Leadership and Spirit, Domingo Conference on Leadership and Spirit, Boston, pp 5-20.

7. Domingo Depaula, P., \& Celeste Azzollini, S. (2012). Inteligencia cultural, valores y motivación para el aprendizaje en estudiantes militares argentines [Cultural intelligence, values and motivation for training Argentinean military students]. Revista de Psicología (PUCP), 30(1), 75-102.

8. Drucker, P. F. (1985). The discipline of innovation. Harvard business review, 63(3), 67-72.

9. Drucker, P. F. (2013). People and performance: The best of Peter Drucker on management. Routledge, India. 10.Drucker, P. F. (2007). Management challenges for the 21st century. Routledge, London.

11.Gloor, P. A. (2006). Swarm creativity: Competitive advantage through collaborative innovation networks. Oxford University Press.

12.Kim, W. C., \& Mauborgne, R. A. (2017). Blue Ocean Leadership. Harvard Business Review, Classics. Press. Korea, 11(67), 23.

13.Livermore, D. (2010). CQ: The Test of your Potential for Cross-Cultural Success. Revista Forbes. $1 / 06 / 2010$.

14.Lyons, R. (2011). Paths to innovative leadership. BizEd magazine, 10(2), 32-38.

15.Marvel, C. M., Rodríguez, M., C., \& Núñez, B. M. A. (2011). La productividad desde una perspectiva humana: Dimensiones y factores [Productivity from the point of view of a person: dimensions and factors]. Intangible capital, 7(2). Consultado el 18 de abril de 2018. Available at: http://www.redalyc.org/html/549/54921605013/.

16.Masood, S. A., Dani, S. S., Burns, N. D., \& Backhouse, C. J. (2006). Transformational leadership and organizational culture: the situational strength perspective. Proceedings of the Institution of Mechanical Engineers, Part B: Journal of Engineering Manufacture, 220(6), 941-949.

17.Merriam, S. B. (1998). Qualitative Research and Case Study Applications in Education. Revised and Expanded from Case Study Research in Education. Jossey-Bass Publishers. San Francisco. Consultado el 10 de abril de 2018. Available at: https://eric.ed.gov/?id=ED415771.

18.Mintzberg, H., \& McHugh, A. (1985). Strategy formation in an adhocracy. Administrative science quarterly, pp. 160-197.

19.Mintzberg, H., \& Quinn, J. B. (1998). Readings in the strategy process, Upper Saddle River, NJ: Prentice Hall, pp. 25-30.

20.Rapaport, R. (2005). Pericles of Athens: Drawing from the essence of strategic leadership. Creative approach to strategic management, pp. 36-44.

21.Sar, L. \& Werneke, D. (1984). Productivity: Problems, prospects, and policies. The Johns Hopkins University Press, Baltimore, pp. 15-125.

22.Rubio, L., \& Baz, V. (2015). El poder de la competitividad [Competitiveness]. Fondo de Cultura Economica.

23.Schumpeter, J. A. (1961). The theory of economic development. Oxford University Press.

24.Velasco y Ramírez, J. M. F. (2013). Representaciones conceptuales de los atributos del liderazgo y de inteligencia emocional en la significación de un líder ideal para el siglo XXI en un contexto organizacional [Conceptual representations about the attributes of leadership and emotional intelligence in the sense of the ideal leader of the XXI century in an organizational context]. (Doctoral dissertation, Universidad Autónoma de Nuevo León).

25.Vitello C., J. M. (2003). Innovative leadership through emotional intelligence. Nursing Management, 34(10), 28-32.

26.Whiting, B. G., \& Solomon, G. T. (1989). Key issues in creativity, innovation \& entrepreneurship. Bearly.

27.Zimmerman, M. A., \& Warschausky, S. (1998). Empowerment theory for rehabilitation research: Conceptual and methodological issues. Rehabilitation psychology, 43(1).

28.Zimmerman, M. A. (2000). Empowerment theory. In Handbook of community psychology. Springer US.

29.Zulma Lanz, M. (2006). Aprendizaje autorregulado: el lugar de la cognición, la metacognición y la motivación [Self-regulation of learning: place of cognition, meta-cognition and motivation]. Estudios pedagógicos (Valdivia), 32(2), 121-132. 